DOl 10.15826/Lurian.2020.1.1.12

УДК 929:616.890

\title{
Luria in Kisegach. Part 1
}

\author{
Tatiana V. Akhutina \\ Lomonosov Moscow State University, Psychology Department, \\ Russia, Moscow \\ Natalia M. Pylaeva \\ Lomonosov Moscow State University, Psychology Department, \\ Russia, Moscow
}

\section{Лурия в Кисегаче. Часть 1}

\author{
Татьяна В. Ахутина \\ Московский государственный университет имени М. В. Ломоносова, факультет психологии, \\ Россия, Москва \\ Наталия М. Пылаева \\ Московский государственный университет имени М. В. Ломоносова, факультет психологии, \\ Россия, Москва \\ Corresponding author. E-mail: akhutina@mail.ru
}

The present article is about A. R. Luria's work and life in Kisegach. It is based on his autobiographical book (Luria A. R., 1982; Cole, Levitin, \& Luria, 2006 [in Eng.]); on the memories of his daughter, Elena Luria, in her book about her father (Luria E. A., 1994); and on a unique document in the Luria family archive: “The Work Diary. Kisegach, 1942-1943”. The general notebook under this name served him for daily records about the examinations of patients and comments on them. This article publishes records entered in the Diary from $19^{\text {th }}$ January until $13^{\text {th }}$ March, 1942.

In the introduction to the publication of "The Work Diary" short biographical material is presented. It gives a description of how A. R. Luria met the beginning of the war, what tasks to create a rehabilitation hospital were assigned to him, how they were carried out. The article presents the memoirs of Luria's daughter Elena (Lena) about the life of their family in Kisegach. It includes the memoirs of B. V. Zeigarnik and S. Ya. Rubinstein on the organization by Luria of labor workshops for the rehabilitation of movements of hand and arms in wounded soldiers. The text is provided with numerous illustrations.

The main part consists of Luria's daily records of patient examinations. Usually he studied from one to four patients. They were patients with aphasia syndromes, with apraxia, agnosia or concussion symptoms. Sometimes Luria gave commentaries to the observed symptoms. He noted the characteristic details of the symptoms and hypothesized the mechanisms of their 
occurrence. In general, the Work Diary shows the intense practical and theoretical work of the scientist while working in Kisegach.

Keywords: Luria's biography; neuropsychology; diagnostics; rehabilitation; aphasia; war trauma; restoration of brain functions.

Эта статья о работе и жизни А.Р. Лурия в Кисегаче написана по материалам его автобиографической книги (Luria A. R., 1982; англоязычное издание - Cole, Levitin, Luria, 2006), по воспоминаниям о Кисегаче его дочери Елены Лурия в ее книге об отце (Luria E. A., 1994) и по материалам уникального документа, хранящегося в семейном архиве Лурия. Это «Дневник работы. Кисегач, 1942-1943» - общая тетрадь с таким названием служила ученому для ежедневных записей о проведенных исследованиях больных и комментариев к ним. В данной статье впервые публикуются дневниковые записи Лурия с 19 января 1942 г. по 13 марта того же года.

Во введении к публикации дневника даются краткие биографические сведения. Описывается, как А. Р. Лурия встретил начало войны, какие задачи по созданию госпиталя были поставлены перед ним и как он их решал. В статье приведены воспоминания Елены Лурия, дочери ученого, о жизни их семьи в Кисегаче. Также используются воспоминания Б. В. Зейгарник и С. Я. Рубинштейн об организации А. Р. Лурия трудовых мастерских для восстановления у бойцов движений рук. К тексту прилагается 9 фотографий.

Основную часть составляют записи А.Р. Лурия в дневнике об исследованиях больных. Обычно он смотрел от 1 до 4 больных в день. Это были пациенты с синдромами афазии, с симптомами апраксии, агнозии, сотрясения мозга. Иногда Лурия комментировал свои “опыты”, он отмечал характерные особенности симптомов и выдвигал гипотезы об их механизмах. В целом дневник является свидетельством интенсивной практической и теоретической работы ученого в госпитале Кисегача.

Ключевые слова: биография А.Р. Лурия; нейропсихология; диагностика; афазия; военная травма; восстановление мозговых функий.

Little Lena Luria was three years old on 21 June, 1941. The war began the next day. Her father, A. R. Luria, wanted to volunteer for the front. He decided to take a photo in the house of his grandparents before parting. This image of 2 July, 1941 was preserved (see Figure 1). However, Luria had to change his plan. In his autobiography, he wrote:

I was commissioned to organize a rear hospital in the opening months of the war. I chose as the site for our hospital a newly established 400-bed sanitarium in a small village near Chelyabinsk. I organized the construction of laboratories and therapeutic training rooms and recruited a team of former colleagues from Moscow to work with me. Within a month the hospital began its work (Cole, Levitin, \& Luria, 2006, p. 139). See Figure 2.

As far as Luria recalled, their work in the hospital solved two tasks: 
We had to devise methods of diagnosing local brain lesions and of recognizing and treating complications such as inflammation and secondary infection that were caused by the wounds. Second, we had to develop rational, scientifically based techniques for the rehabilitation of destroyed functions (Cole et al., 2006, p. 139).

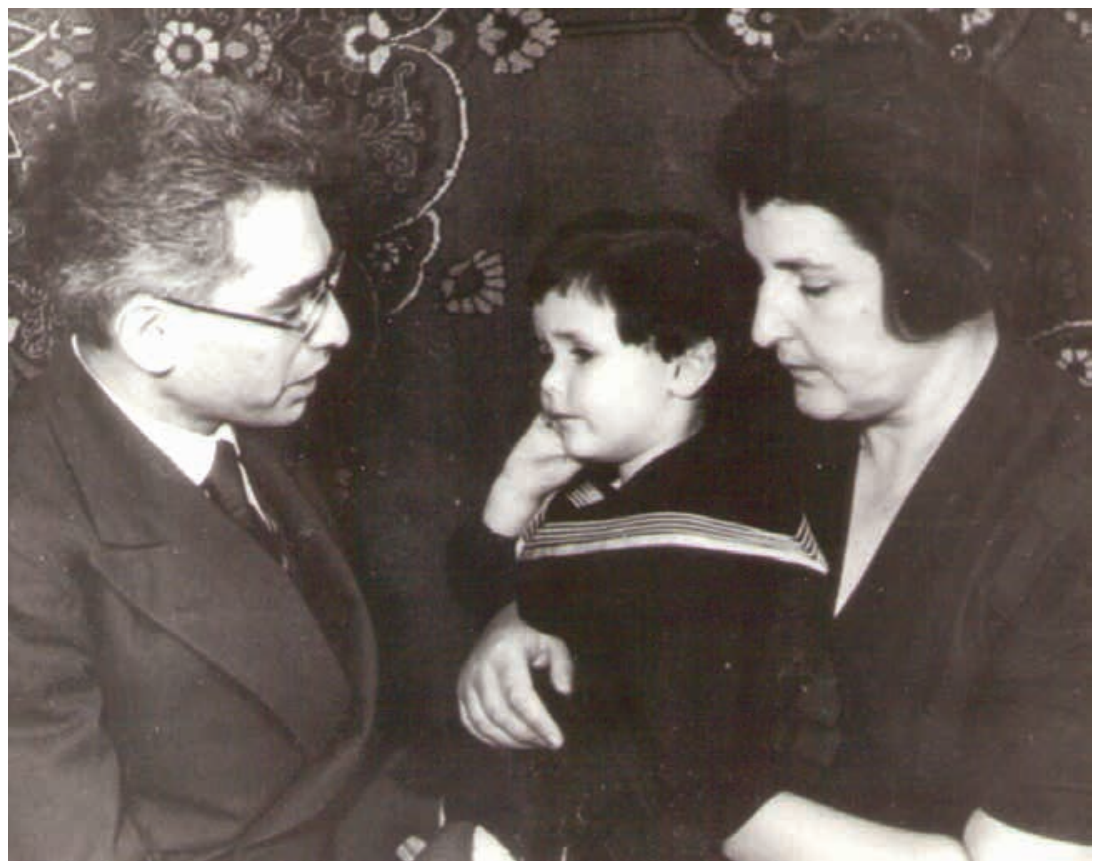

Figure 1. The Lurias. 02.07.1941: himself, his daughter Elena and his wife Lana Lipchina
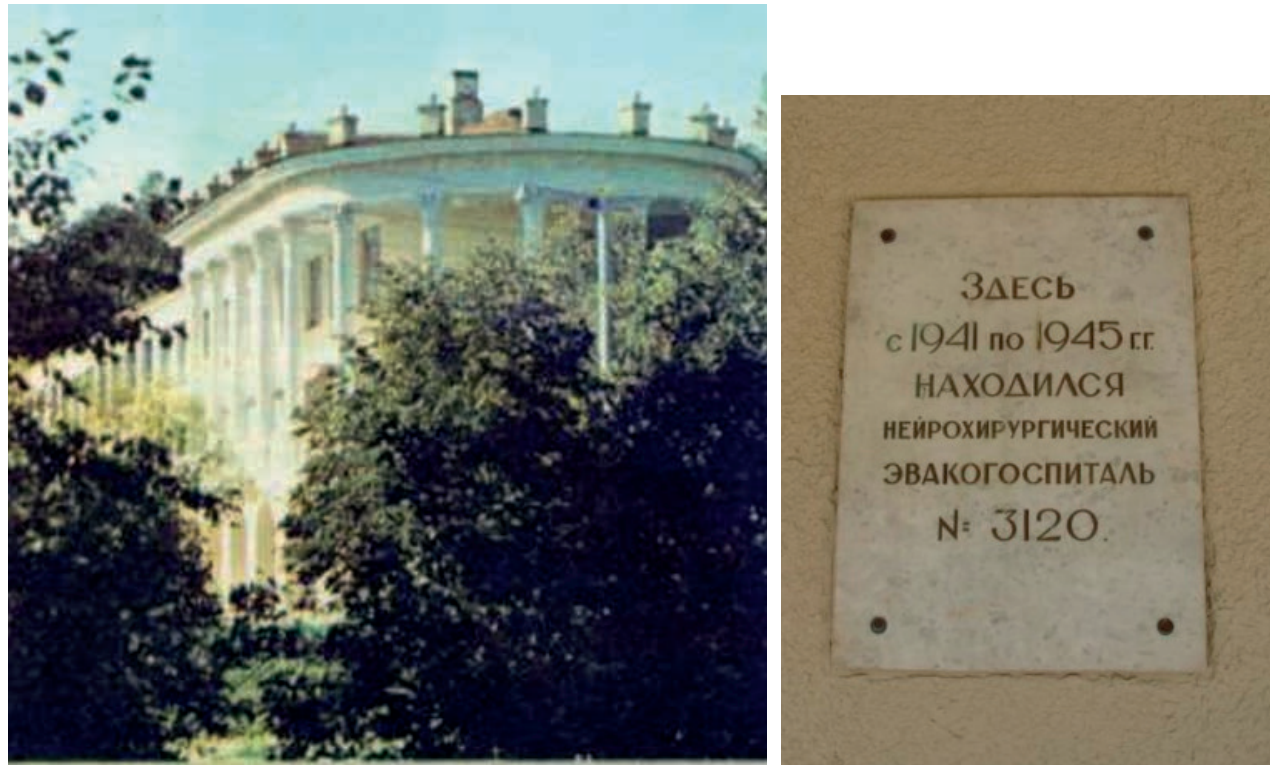

Figure 2. The building of the sanatorium and a plaque about the hospital (modern photo) 
A team of 30 people worked in Kisegach under Luria's guidance (see Figure 3). Among the psychologists, there were B. Zeigarnik, A. Zaporozhets, S. Rubinstein, E. Bein, and O. Kaufman.

Luria's pre-war studies were a starting point for the development of diagnostic and rehabilitation methods.

Elena Luria ${ }^{1}$ wrote in her book:

The small village of Kisegach lay between two lakes. On the shore of a smaller lake with calm water, overgrown with water plants, there were two two-storied buildings of the sanatorium. In them, they established a hospital without any rebuilding: they made hospital wards and operating theatres... The hospital had the balneary facility built for the sanatorium. After some time, neurophysiological and pathomorphological laboratories were opened, the equipment of which was more than modest... In the basement, where previously there was a billiard room, Alexander Luria set up rehabilitation and labor workshops for wounded soldiers: carpentry, plumbing, sewing, shoe workshops and accounting courses... (Luria E. A., 1994, p. 100).

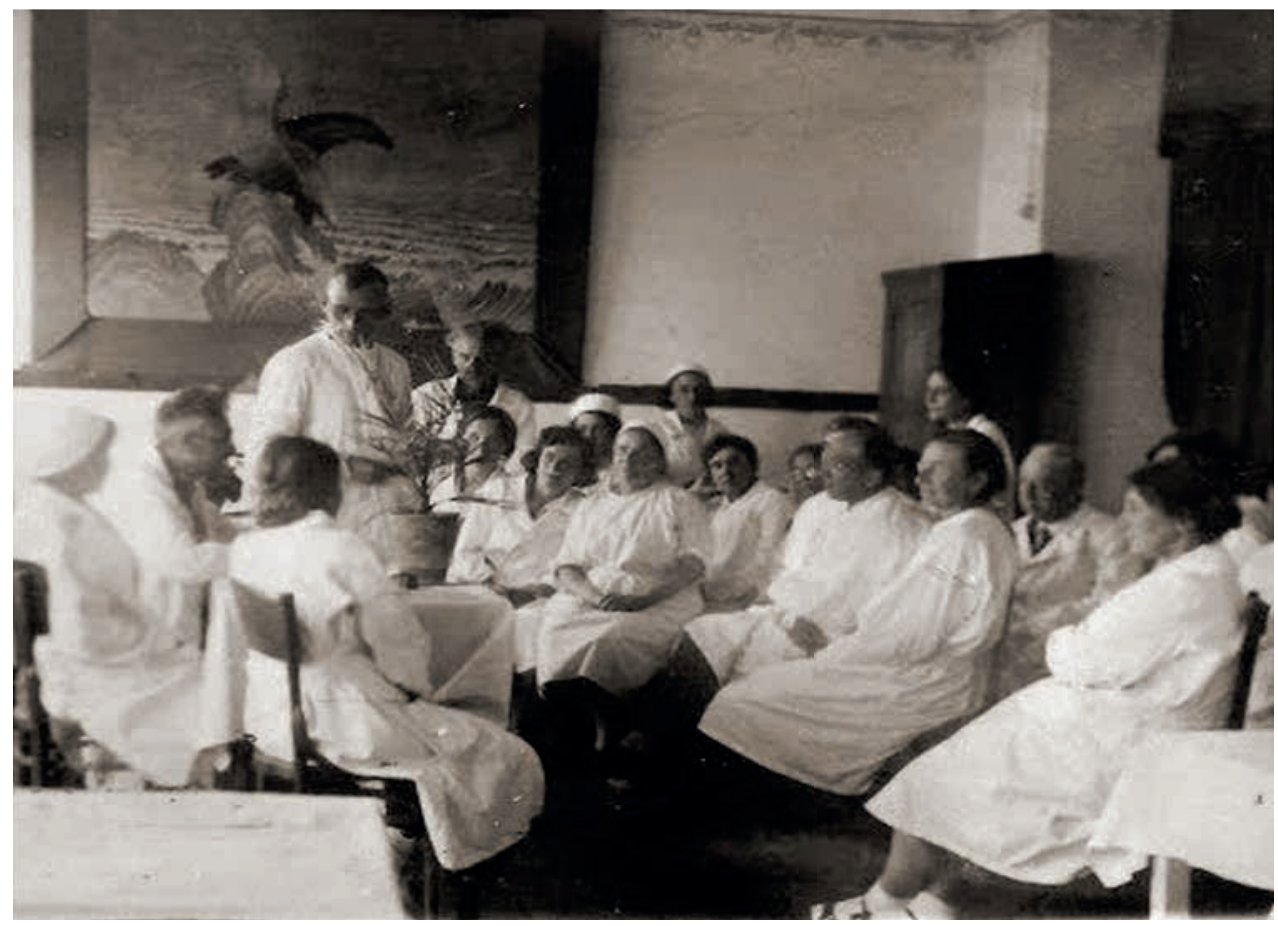

Figure 3. Hospital staff meeting, second left A. R. Luria. From "Going to Visit Luria: A small trip of a Volunteer Group," by Volunteer group of the SUSU "Flame," 2015. Retrieved from https://psyrazv.susu.ru/372-2/. Copyright 2015 by the South Ural State University

${ }^{1}$ E. A. Luria (1938-1992) was a successful research biologist, and a gifted author of children's stories and popular science books. Her book about her father, published in 1994 in a small edition, has long been a bibliographic rarity. 
Zeigarnik and Rubinstein (1982) pointed out the difficulty of the tasks Luria faced and the importance of the rehabilitation of patients in the workshops. Sharing their memories, they wrote:

The working conditions in the hospital were difficult. There was a war going on, and great numbers of wounded persons suffering from a long road were daily delivered to the hospital. And here, in those difficult conditions, Luria deployed not only treatment but also rehabilitation from the very beginning. He selected necessary personnel $<\ldots .>$ arranged a room for EEG and therapeutic gymnastics. And the most surprising thing was that large and well-equipped workshops were quickly established under his guidance (Zeigarnik \& Rubinstein, 1982, p. 70).

The purpose of the workshops was twofold. The first was to help the soldiers with limited abilities and no profession to perform physical work and become tailors, shoemakers, carpenters, accountants and locksmiths. The second important aim was to rehabilitate the movement of hand and arms. They designed and manufactured special devices in order to hold the tool with injured semi-paralysed hands and arms. Neurologists helped to select which movements were the most effective to the patient. Physiotherapy and physical therapy were used. The wounded persons received a specific labour task during which they performed useful movements. A meaningful work task stimulated patients. In fitting and carpentry shops, they performed most movements with two hands. First, a paretic hand was a "passenger": the work with the tool was performed by a healthy hand. The repetition of such operations during the months led to the inclusion of the paretic hand in the work. The joint efforts of instructors in therapeutic exercise, neurologists and psychologists yielded perfect results. Wounded soldiers acquired labour skills (Zeigarnik \& Rubinstein, 1982).

Elena Luria wrote:

Alexander Luria never went but always ran along the territory of the hospital. He delved into everything; there were no unimportant details to him. Many of those working with him in the hospital told me how Alexander Luria helped them, and did it imperceptibly, on the run. Luria made great efforts so that employees received rations and were not starving...

He participated in receiving wounded persons and carried the soldiers out of the sanitary echelon. Among the soldiers arriving at the hospital, there were Uzbeks and Tajiks who did not speak Russian. Alexander Luria came into the room of soldiers from Central Asia, took a seat on the bed and began speaking in their native language (Luria E. A., 1994, p. 101).

As to the everyday life in Kisegach, Elena Luria wrote:

We lived in a small wooden house on the hill in Kisegach. A snowy and cold winter came. I sat in the kitchen near the stove and watched Olya (Elena's babysitter living with the Lurias for 60 years) cooking the dinner of dried potatoes. These were shrunken gray-brown disks strung on a thread like dried mushrooms... It was very difficult with food during the first 
winter; and then we settled down somehow. We got a kitchen-garden, and my mother and Olya planted potatoes. The mushrooms that we salted for the winter were a great help... (Luria E. A., 1994, p. 112, 135). See Figure 4.

\section{Elena recalled:}

A lot of snow fell that year snowing hummocks and glades. Roads were covered, and people trampled narrow paths. When the snow was being added the paths became deeper and deeper. And long snow corridors turned out to be on a par with my height (Luria E. A., 1994, p. 112).

Here are Lena's memories about her mother, Lana Pimenovna Lipchina: ${ }^{2}$

When the hospital needed radon for baths, my mother, who first worked as a nurse and then organized a histological laboratory, went to Moscow to get an ampoule with a radioisotope. She drove it on her chest. The train took a long time, stopped often, and my mother reached Kisegach almost in a week. Returning from Moscow, she lost a lot of weight and felt very ill (Luria E.A., 1994, p. 136).

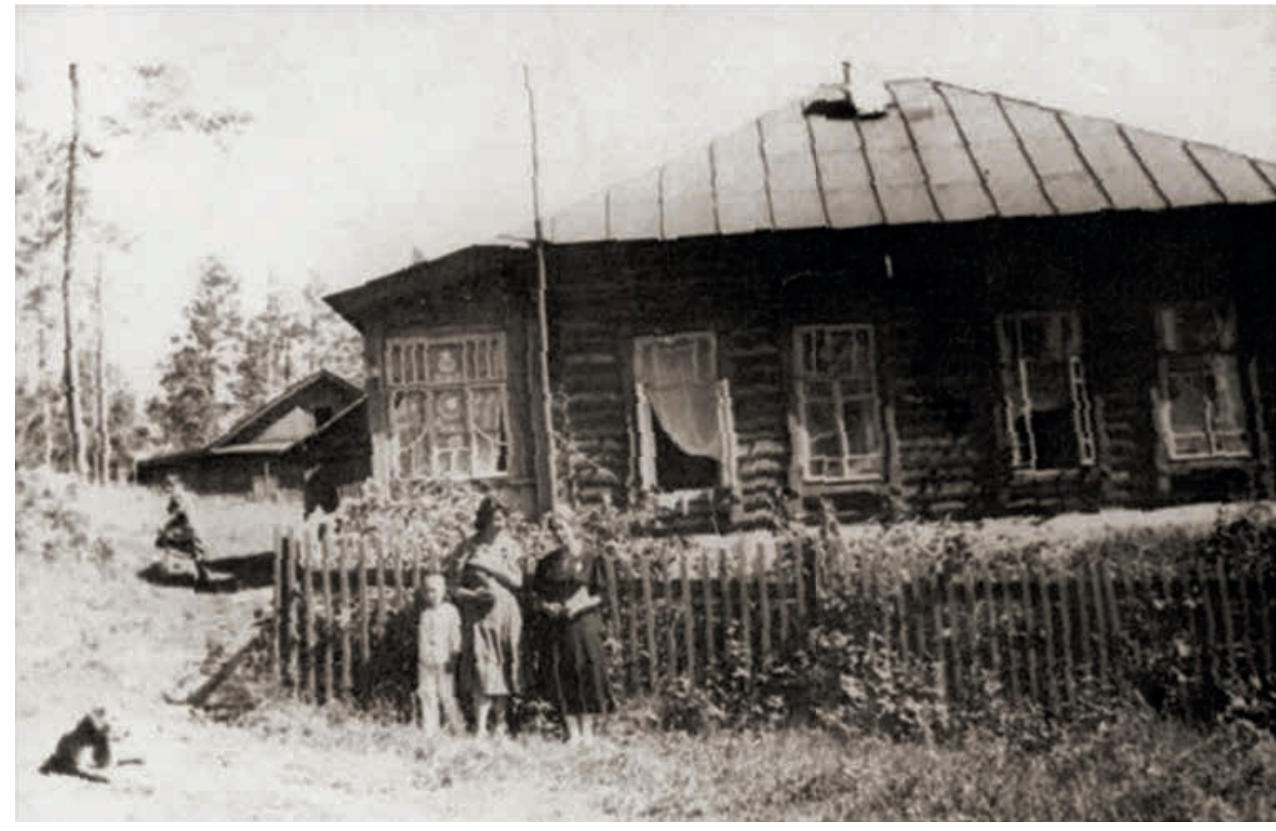

Figure 4. The house where the Luria family allegedly lived in 1941-1944 (photo from an album stored in the family archive of Luria)

2 L. P. Lipchina (1904-1978) became A. R. Luria’s wife in 1933, got her PhD in 1937 and DSc in biology in 1954. At the end of 1938, she began working in the Institute of Neurosurgery where she gathered a group to cultivate brain tumors beyond the organism. On returning from Kisegach, she went on working at cultivating tumor-tissue cultures. 
Much later, she understood that she had been exposed to radiation and had suffered radiation disease. Only owing to her strong organism and resistance, she could return to work in the hospital and continue living and working actively (see Figure 5, 6).

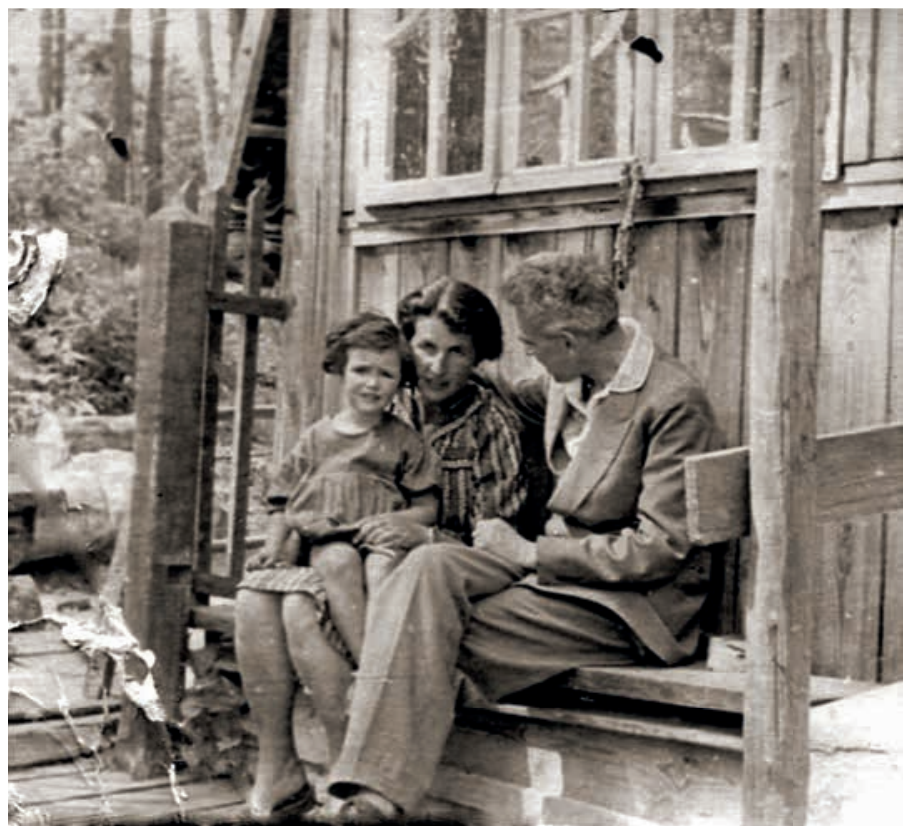

Figure 5. The Lurias near the house in the village of Kisegach

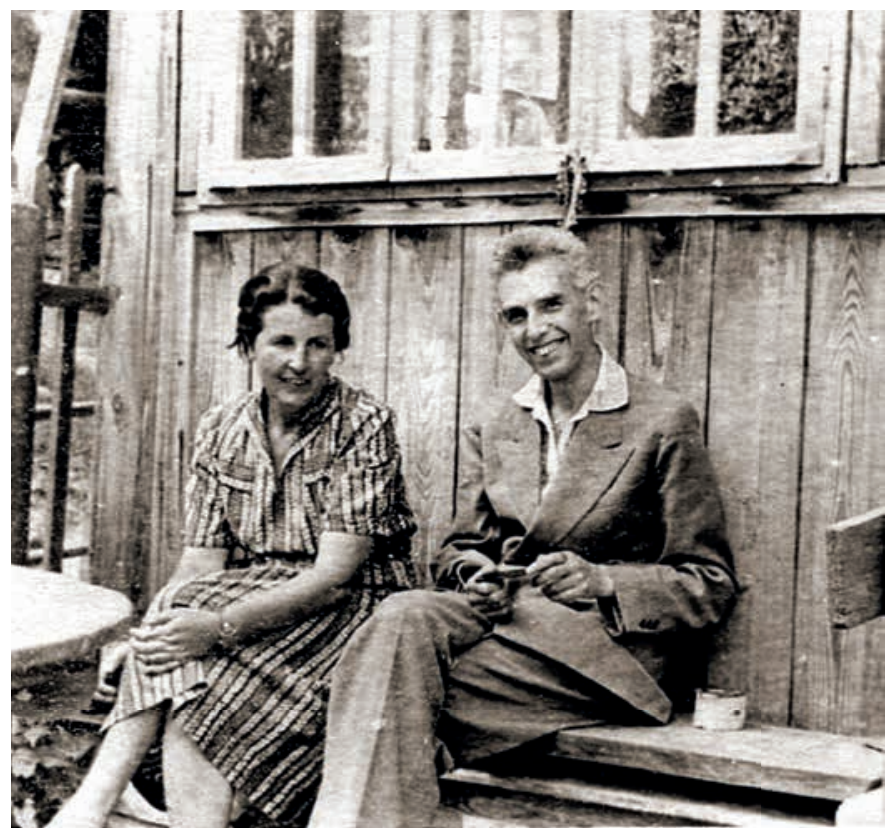

Figure 6. Alexander Luria and Lana Lipchina in Kisegach 
Radon revealed itself many years later. In 1977, Lana Lipchina was diagnosed with cancer. She was hospitalized and operated on; she had cancer with metastases. Her diagnosis was hidden from Luria. But one day, having come to his wife in the hospital, and awaiting an appointment with the doctor, Luria saw his wife's medical history and read the diagnosis. It was soon after July 16 , when his friends and colleagues congratulated him on his 75th birthday. After Lana's discharge from the hospital, the couple went to the Uzkoe sanatorium near Moscow. In the evening of 14th August, Alexander Romanovich went down to the lobby to call one of his acquaintances and ask them to help him get a rare medicine for Lana Lipchina. In the phone booth, he felt sick and fell down. The doctor on duty could not help. A. R. Luria died of cardiac arrest. On his desk in the hotel room, there remained the unfinished "Paradoxes of Memory".

Lana Lipchina outlived her husband by five months.

Let us get back to Kisegach (see Figure 7). According to Zeigarnik and Rubinstein, A. R. Luria and the commissar of the Hospital Chekalin managed "to create an exemplary medical rehabilitation institution in difficult conditions" (Zeigarnik, Rubinstein, 1982, p. 71). Luria worked not only with patients within the framework of the neuropsychological research and rehabilitation but also he organized scientific conferences and released manuals that were distributed among other hospitals. In the list of his papers, there were four articles that dated back to 1942-1943 on the rehabilitation of functions (Luria A. R., 2003). These were the only articles that appeared in the main press in neurological journals.

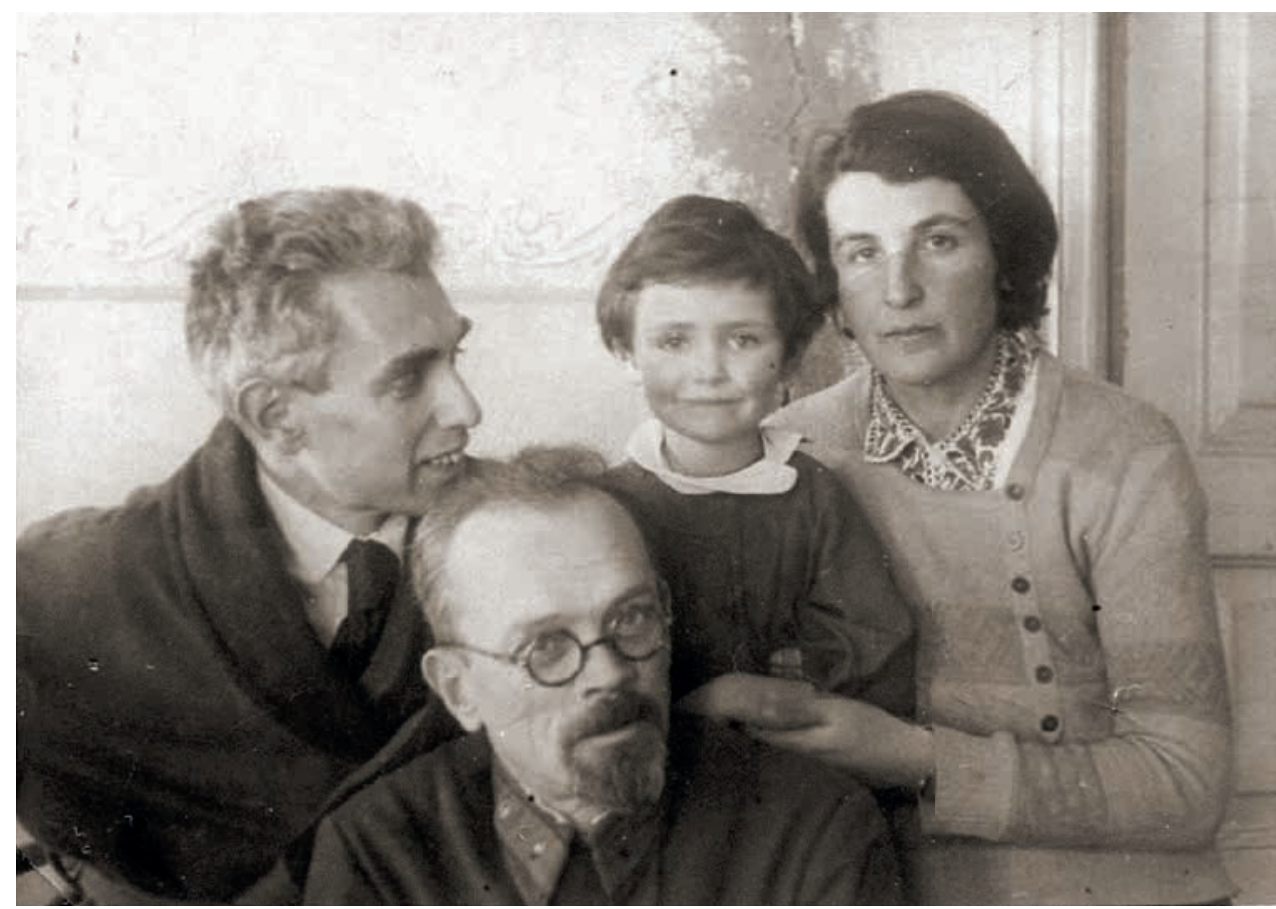

Figure 7. The Lurias and an unknown person 
Luria edited the text of the book "Temporal (Sensory) Aphasia" which he prepared for his doctoral thesis in medicine. This was the first volume of "The Study of Aphasia From the Point of View of Brain Pathology" written in 1940; the second volume was about semantic aphasia. Both volumes remain unpublished (Luria A. R., 1940). The second book was described by T. V. Akhutina and A. R. Agris (2018).

In Kisegach, Luria prepared the manuscript of the book "Essays on the Theory of Traumatic Aphasias" (Luria A. R., 1943). This book has been preserved in the family archive as well. It has 138 typewritten pages. The title page reads: "Rehabilitation Branch of the Neurological Clinic of the All-Union Institute of Experimental Medicine. Neurosurgical Rehabilitation Hospital of the All-Union Central Council of Trade Unions". The author's name and the title "Essays on the Theory of Traumatic Aphasias" appear below, with "Kisegach 1943" at the bottom.

The book has three sections. The first two sections are very similar to the text of Part One of "Traumatic Aphasia", Chapters I and II. The third section corresponds to the sections of Part Two, Chapters III-VII. Thus, "Essays" are a draft of "Traumatic Aphasia". The date of 14th August, 1943 is shown on the last page of the Essays. This draft book and two volumes written in 1940 require a thorough analysis to identify the path to the classic description of aphasia syndromes, outlined in "Traumatic Aphasia".

\section{The Work Diary}

"The Work Diary. Kisegach, 1942-1943" is kept in the family archive. Elena Luria said that her father "never threw away a single piece of paper in his life". Of course, this is an exaggeration, but he did indeed leave a very large archive. The oldest part includes records of the investigations of speech in the 1920s, records from the Central Asian expedition, and many other documents, which are kept at their dacha in the village of Svistukha (The Moscow Region). The main part is in Moscow with Elena Georgievna Radkovskaya, the grandniece of A. R. Luria, who is the keeper of the archive. A small part of the archive, preserved by Professor E. D. Khomskaya, Luria's closest co-worker, is now on the premises of the Laboratory of Neuropsychology, Faculty of Psychology, Lomonosov Moscow State University (the keeper is T.V. Akhutina). The faculty archive contains more than 10,000 pages of material from the 1920s to the 1970s that incorporate nearly the entire research activity of the famous scientist. In 2016-2017, the documents of this part of the archive were converted into an electronic form. They will soon be available on the archive's website.

"The Work Diary" is a 48-sheet notebook without any page numbering. As a rule, the text is on the left page, and the right one is for comments. The same arrangement of material is used by A.N. Leontiev. The notes of Vygotsky's talks on "The Problem of Consciousness" are outlined in the same way (Vygotsky, 1997). In the text below, comments from the right pages appear immediately after the records to which they relate. There are many abbreviations in the text; all of the abbreviations are expanded in this publication. In obvious cases they are not specifically marked, but in the most difficult places the dis- 
closure is given in [square] brackets. Illegible words are marked with <angle > brackets, and inserted words are in \{curly\} brackets. All of the author's underlines are preserved; a single underline is conveyed respectively, double underscores are passed in bold with underscores.

The diary covered the period from $19^{\text {th }}$ January, 1942 until $22^{\text {nd }}$ July, 1943. In 1942, 74 entries were made, with 30 of them presented in this publication. Luria left for Moscow in late April and returned to Kisegach on 12 May (based on the letter to Sergey Eisenstein of $11^{\text {th }}$ May, published in Elena Luria's book, 1994). Diary entries resume in mid-June. At the end of July, Luria went to Kazan. There were no records in December, 1942. There were 67 entries in 1943; most of them were made between January and April. In May, there was one record: "Preparation for a dissertation, preparing for a conference". This entry is very important. The Internet has links to 1942, 1943, and 1944 as years of defense of the dissertation. The English edition of the book by E. D. Homskaya, "Alexander Romanovich Luria. A Scientific Biography” specified 1944 (Homskaya, 2001), and Wikipedia specifies 1943. Provided this, one might think that the defense took place in 1943. It is most likely that the higher attestation commission approved it in 1944.

The diary entries ended on 22 July, 1943, but Luria went on working at the hospital. He returned to Moscow in October of 1944, continuing to run the hospital until November, 1944.

Let us attend to the Diary. The cover and a page of the diary are shown in Figure 8 and Figure 9. The Russian text of the Diary is presented in the Appendix.

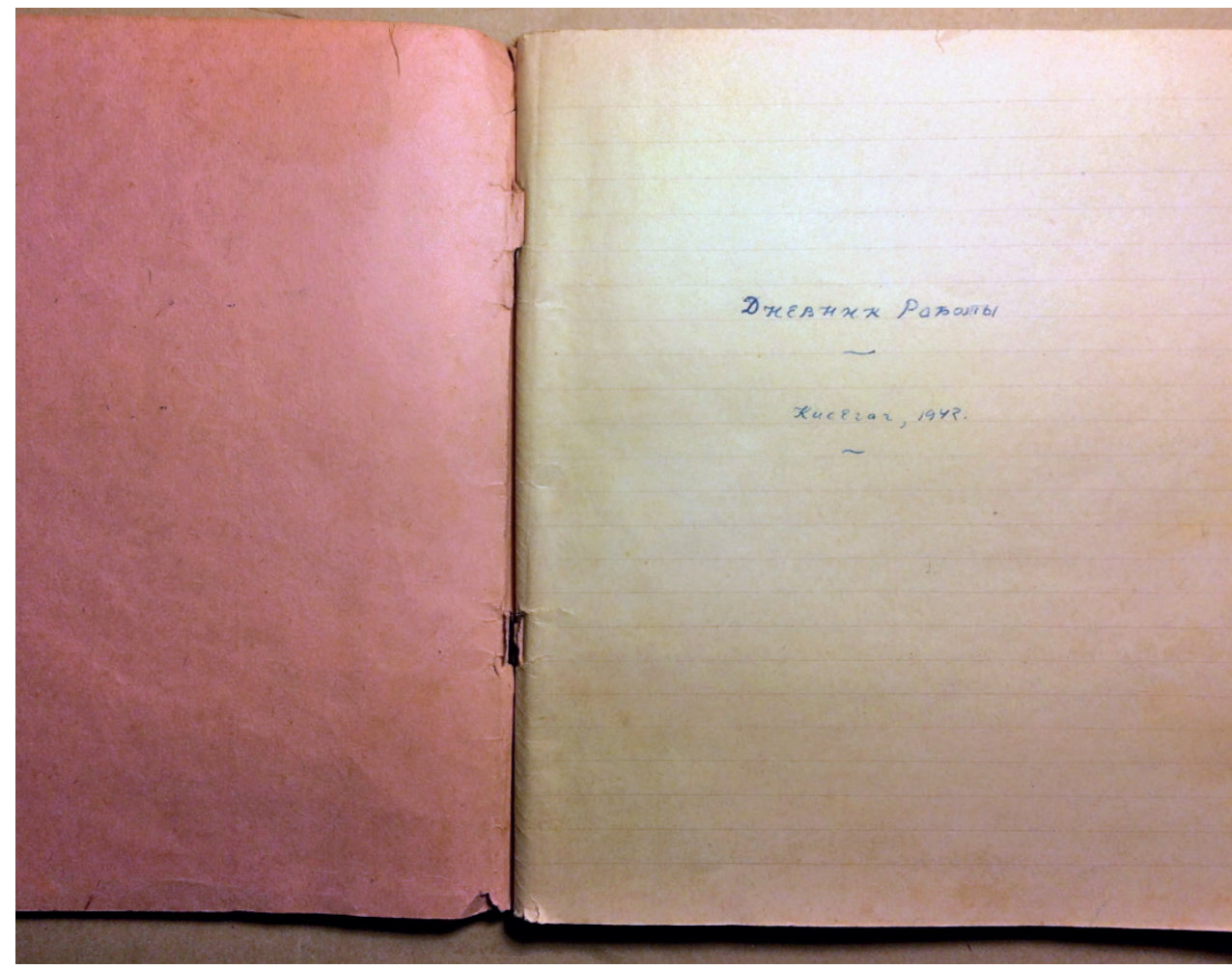

Figure 8. The cover of "The Work Diary" 


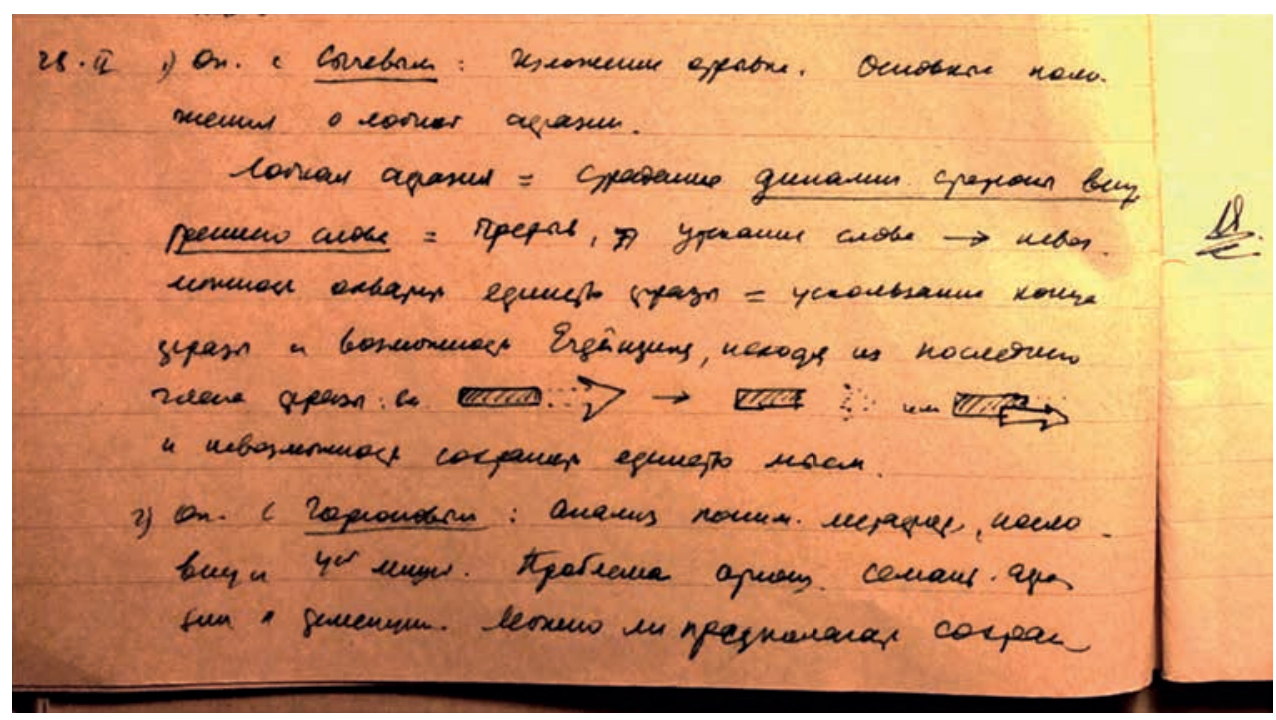

Figure 9. A fragment of one of the pages of the "Diary" with an entry dated 28.02.1942

\section{The Work Diary}

\section{I.42}

The discussion of experiments with a concussion patient ${ }^{3}$ (Dekhterev).

a) The mystery of slowness; deciphering the slowness as a result of systemic disintegration, and hence $\rightarrow$ voluntarizing ${ }^{4}$ \{making something voluntary\} all the components.

b) Memory: the flow-away of the traces of memory! the interweaving of any components in amnestic terms (the experience with the reproduction of the tale, [interlaced] by other ff $\{$ functions $\}$ ).

c) Preservation of the logical components.

\section{I.42}

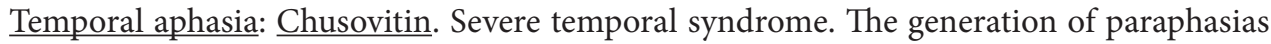
because of the non-retention of verbal images (fuzziness of $<$ Bereiche $\rangle^{5}$ ),

- a test for repeating [double] words

(Planning the Bein's ${ }^{6}$ theme $\{$ of her scientific work $\}$ ).

${ }^{3}$ Concussion syndrome is a set of general brain symptoms caused by mechanical trauma to the brain.

${ }^{4}$ The author's neologism.

${ }^{5}$ See entry from 9.II.42 and footnote 11.

${ }^{6}$ E.S. Bein - a well-known psychologist-aphasiologist and a staff member of the hospital, who defended her dissertation on sensory aphasia. In "Traumatic Aphasia”, Luria refers to her research 11 times. 


\section{I.42}

A trial with Soskov: (1) Pseudo-semantic disorders (materials to separate temporal-aphasic from semantic disorders (semantic disorders in the non-retention of verbal images - [cf.] a primary preservation of semantic relations, the state of intelligence).

(2) The preservation of narrative speech.

On the right side: The trial on narrative speech:

\{it is\} impaired in frontal aphasias (cf. a sharp dissociation of reactive \{responsive and narrative speech in Svetlov, etc.);

\{it is preserved $\}$ - in temporal and parietal impairments (this type of dissociation is absent: cf. [Gtevich], Soskov, etc.)

\section{I.42}

The experiment with Usatov: Motor Skills: A typical example of subcortical motor impairments: disturbances of motor postures + dysmetria + positional apraxia but all types of voluntarily organized movements are preserved.

NB: Injury temple-subcortex $\rightarrow$ premotor movements are good!!

On the right side: NB: Motor Skills:

1. Premotor disturbance (pure) - no kinetic melodies, schemes...

2. Premotor-subcortical impairment - no kinetic schemes + excessive movements (cf. Nurmukhanov, cf. Alipov!).

\section{Pure subcortical \{impairment\}}

(temporal subcortical [impairment] $\rightarrow$ positional disturbances, no excessive movements)

(cf. temporal access \{during the operations\} the group!: Fedorov, Usatov!)

\section{I.42}

Experiment with Fedorov (pure temporal-subcortical syndrome)

(1) The absence of aphasia in the left anterior-subcortical region

(2) An entire preservation of the structure of intellectual operations with its dynamics disturbance (Sperrung ${ }^{7}<3$ letters illegibly $>$ )

(3) Mnestic disintegration - of knowledge (the rest of concussion syndrome!)

(4) The development of quantitative tests for exhaustion.

On the right side: Compare negative cases of temporal lesions

Fedorov: anterior-temporal syndrome: only amnestic components in the voluntary speech in the absence of amnesia in naming = the deactivation of speech: the disturbance of the unity of thinking-speech (dynamics).

\section{I.42}

(1) Experiment with Blinnikov: an Example of a functional protragated ${ }^{8}$ aphasic syndrome!! NB! $^{2}$

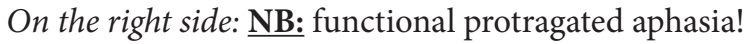

\footnotetext{
7 Die Sperrung (Ger.) - blocking.

${ }^{8}$ Protragated - protracted.
} 
(2) The development of a brief scheme of the examination of patients with concussion (with Zeigarnik). ${ }^{9}$

\section{II.42}

Analysis of Bashinsky. 1) Frontal syndrome of thought disorder: the disorder of thinking activity: the intent, the creation of a mental Bereich ${ }^{10}$ and "casting a fishing rod in the future".

A frontal patient is unable to create the PROBLEM (i.e., an empty Bereich which coordinates the relevant reasoning, and to which the reasoning flow is equalized); it is impossible for him to experience an error, a genuine act of control and so on. Everything is replaced by Kurzschluss'es ${ }^{11}$ and thought flow by the type of Ergänzung ${ }^{12}$ to the whole;

Both topic and a dialogue are impossible for him.

On the right side: NB: Dialogue as a method of bringing out the inner dialectic of the patient!

\section{II.}

Experiment with Duriagin: the subcortical suffering of thinking: it is based on de-automatization, "thinking not immediately" but all the complex forms of intellectual processes are entirely preserved, primary memory and primary volitional set are preserved.

\section{II.}

1) Experiment with Usaykov. Specific features in thinking in subcortical lesions: impairments in the first link - grasping: [here] the clarity of the structure is replaced by contamination, and hence it is built on dream-based mechanisms, the further flow of thinking is quite possible

2) Experiment with Menshik: a clear frontal syndrome of stereotypes

NB: $100-2: 89-83,79-73,69-63$

On the right side: $\underline{\mathrm{NB}}$

\section{II.}

1) The analysis of Kadashev. A clear syndrome of basal frontal lobe: a complete loss of affective generalization!

On the right side: the disintegration of affective generalization!

2) Experiment with Belov: one more subcortical frontal syndrome (slowness, [no attitude]).

On the right side: NB: Fedorov et al.

16.II.

1) Experiment with Kondratiev and Shevchenko: the right frontal lobe [gives] invariably a failure in the perception of rhythms despite the ability to perform that.

9 B. W. Zeigarnik (1900-1988) is a famous pathopsychologist, a student of K. Levin and L. S. Vygotsky, she was a staff member of the hospital.

${ }^{10}$ Der Bereich (Ger.) - region, field, i. e. Luria means the activation of a semantic zone, fixing the content of the future statement / plan of activity.

${ }^{11}$ Der Kurzschluss (Ger.) - electrical short, in the figurative sense - impulsive guess.

12 Die Ergänzung (Ger.) — addition. 
On the right side: NB: The right frontal lobe = operating the time.

2) Experiment with Shevchenko: the patient once developed a stereotype after reading the fragment ("one owner had a hen that laid three eggs"13). He not only retained this stamp for 3 weeks and after a single reading gave it 3 weeks later, - but was unable to succumb to retraining, and - even after repeated reading explaining the error — still continuing to give it!!

On the right side: $\mathrm{NB}$

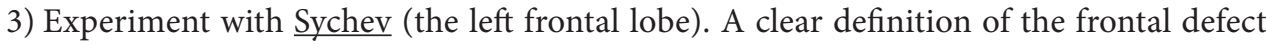
of intelligence:

a) The disruption of the normal relations of thought and speech: "The language goes ahead of thought", and his slips of the tongue by type of insertion are "slips of inattention".

On the right side: NB: To the frontal aphasia!! (not Broca's but the aphasia of frontal impairments of the unity of thought and speech).

b) The disturbance of thinking is not in the cognitive operation itself (for instance, counting) but in the inability to keep the conditions in memory.

Again, here is a peculiar defect of memory for thoughts - both the memory itself and intelligence itself are entirely preserved (compare: a complete preservation of tests for memorizing words).

17.II.

1) Experiment with Usatov. The disturbance of thinking is in the disturbance of direction, set.

2) Experiment with major Novitsky: with a relative general safety - the disturbance in the performance of rhythms.

On the right side: Compare: the right frontal lobe!!

\section{II.}

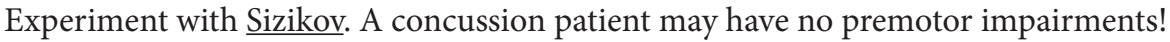

\section{4-25.II.}

Experiment with Goryunov. A pure semantic aphasia (= the impossibility to Zusammensehen ${ }^{14}$ semantic structures!).

26.II.

1) Experiment with Goryunov. Typical problems, hesitations of a semantic aphasic patient ("more light = less light", etc.).

2) Experiment with Sychev - the Inability to turn from the plan to a coherent description, narration.

On the right side: The plan of frontal aphasia.

3) Experiment with Usatov. Primary amnesia in subcortical ailment.

${ }^{13}$ A. R. Luria usually told the patients the story: "One owner had a chicken laying golden eggs. He wanted more gold and killed the chicken. But there was no gold inside". The patient replaces the words "golden eggs" with "three eggs". Then he repeats these words stereotypically.

${ }^{14}$ Zusammensehen (Ger.) - here and hereinafter, simultaneous vision. 


\section{II.}

Experiment with Goryunov. The analysis of the structure of the phrase (Passive voice) "The sun is illuminated by the earth". The mechanism of the assessment of the phrase is a mechanism of practical words placement and the recognition of the right meaning. The analysis, comprehension of sense is impossible.

\section{II.}

1) Experiment with Sychev: the narration of the fragment. The main statements of frontal aphasia.

Frontal aphasia $=$ suffering of the dynamic side of the inner word $=$ The interruption, flowaway $^{15}$ of the word $\rightarrow$ the inability to embrace the unity of the phrase $=$ the elusion of the end of the phrase, and the possibility of Ergänzung based on the last part of the phrase: see $\mathbf{m} \mathbf{m}====>$

\section{$\rightarrow+\cdots+\cdots>$ or $m$}

and the inability to maintain the unity of thought (see the scheme of Luria in Figure 9).

On the right side: NB

2) Experiment with Goryunov: The analysis of the understanding of metaphors, proverbs and the Odd one out test. The problem of the relationship of semantic aphasia to dementia. May one expect that categorical thinking is preserved in the disturbed Zusammensehen??

3) Experiment with Goryunov: a test that reveals the feature of patients' reactions/responses to a long-term work.

\section{III.1942}

Experiment with Goryunov: 1) The ability to grasp the relations of generality!! 2) The preservation of general ideas - with amnesia for them - and when slipping into a particular plan!

On the right side: curly bracket to 1) and 2) NB!

\section{III.42}

1) Experiment with Karabanov (premotor aphasia) 1) a pure form of de-automatization; 2) a disturbed grasping "not immediately".

On the right side: NB: One of the main phenomena: de-automatization of grasping! (a dynamic impairment of intellectual [processes])!!

2) Experiment with Goryunov: the dynamics of concepts: the possibility of comparison and generalization — but the trend toward slipping into the plan of complex thinking.

\section{III.42}

1) Experiment with Goryunov. Analogies. The ability to master the analogy and transfer! Secondary difficulties are in this.

2) Usatov. Difficulties in memorization (the primary memory impairment - memorizing a meaningful text is easier than memorizing a poem).

\footnotetext{
${ }^{15}$ The author's neologism.
} 


\section{III.42}

Experiment with Goryunov. Counting. The inability to immediately evaluate a multi-digit number. Grasping a multi-digit number (a) by a visual analogy or (b) by means of superimposing an external grid.

\section{III.}

The scheme of frontal aphasias ${ }^{16}$

\section{Broca's Aphasia}

(its close inverse relationship with Wernicke's area.

Sound agraphia at $<$ testing $>$

its close feedback to the parietal zone:

semantic disturbances at $<$ testing $>$ )

Shcherbakov!

Premotor Aphasia

Speech de-automatization, [motor], [grasp]

The denervation impairment of writing,

Merskalov,

a relative preservation of thought

Karabanov

Frontal Aphasia (or Para-aphasic state)

(the disruption of the relationship of thought with speech - inner speech.

Sychev

Tearing thread of thought,

Disturbance of narration, storytelling, dynamics of Aussage ${ }^{17}$ and Propositional speech ${ }^{18}$ )

\section{III.42}

1) Experiment with Goryunov. Counting: The difficulty is not in the concept of number, digit, sign, - but in grasping the number, combining its components in operations (especially in mind).

2) Experiment with Karabanov: a) The sharpest aspontaneity of speech — the inability to proceed from the internal plan, the inability for a narrative speech

b) The availability of "Ergänzungsfragen" (direct questions) and the unavailability of indirect questions (requiring a layer of thinking)

On the right side:

NB: direct questions (Ergänzungsfragen ${ }^{19}$ ) + cf. average child

${ }^{16}$ The proposed classification of frontal aphasias differs from the previous and subsequent ones. Here, under the name of frontal aphasia, dynamic aphasia is introduced. "Premotor" aphasia is described in "Traumatic Aphasia" as "speech disorders in the lesion of the "marginal" zones of the premotor region" (Luria A.R., 1970; see also Akhutina, 2016).

${ }_{17}$ Die Aussage (Ger.) - statement.

${ }^{18}$ Propositional speech (Eng.) - from proposition, statement, that is, predicative narrative speech. Luria quoted the H. Jackson's $(1868,1869 / 1932)$ statement "To speak is to propositionize" (Luria A. R., 1976, p. 37).

${ }^{19}$ Ergänzungsfragen (Ger.) - questions that require additions. In "Traumatic Aphasia" Luria distinguishes two types of questions in dialogic speech. Some do not require any search for new formulations ("Did you have lunch today?" "Can you read?"); others (for instance, "How were you injured?") require the patient "to show a special activity in finding new formulations" (Luria A. R., 1970). 
indirect questions (requiring - age 2-2,5 years

a layer of thinking!)

\section{2-13.III.42}

1) Experiment with Moiseyev: A severe parietal and temporal aphasia

2) Gdevich (Kaufman \{O.P. Kaufman\}) - an entire preservation of rhythms.

On the right side: NB!!!

3) Experiment with Karabanov: A gross violation of the expounding (narrative) speech; disorder of active forms; disorder of grasping.

\section{To be continued}

\section{Acknowledgements}

The authors have the pleasant task of expressing their warm thanks to Elena Radkovskaya for the opportunity to reproduce "The Work Diary" and valuable photos (Figure 1, 4-7) of the family archive. They are grateful to Natalia Kozlova for her help in typing Russian text.

\section{References}

Akhutina, T. (2016). Luria's classification of aphasias and its theoretical basis. Aphasiology, 30 (8), 1-20. Akhutina, T. V., \& Agris, A. R. (2018). History of studying semantic aphasia mechanisms (based on materials from Lurian archive). In J. M. Glozman, O. S. Vindeker, I. A. Ershova, \& M. E. Permiakova (Eds.), The Fifth International Luria Memorial Congress "Lurian approach in international psychological science”, KnE Life Sciences, 30-41. https://doi.org/10.18502/kls.v4i8.3260

Cole, M., Levitin, K., \& Luria, A.R. (2006). The autobiography of Alexander Luria: A dialogue with the making of mind [Rus. ed.: Luria, 1982]. Mahwah, NJ: L. Erlbaum Associates.

Homskaya, E. D. (2001). Alexander Romanovich Luria. A scientific biography. New York: Kluwer.

Jackson, H. (1868, 1869/1932). Notes on the physiology and pathology of language. In Selected Writings. London: Hodder \& Stoughton.

Luria, A. R. (1940). The study of aphasia in the light of brain pathology: Pt. 1. Temporal (acoustic) aphasia, Pt. 2. Parietal (semantic) aphasia. Unpublished manuscript. The E. G. Radkovskaya archive, Moscow. [In Russian]

Luria, A. R. (1943). Essays on the theory of traumatic aphasia. Kisegach. Unpublished manuscript. The E. G. Radkovskaya archive, Moscow. [In Russian]

Luria, A. R. (1970). Traumatic aphasia [Rus. ed. 1947]. The Hague: Mouton.

Luria, A. R. (1976). Basic problems of neurolinguistics [Rus. ed. 1975]. Hague: Mouton.

Luria, A. R. (1982). Steps of the passed way: Scientific autobiography. Moscow: Moscow University Press. [In Russian]

Luria, A. R. (2003). Psychological heritage. Moscow: Smysl. [In Russian]

Luria, E. A. (1994). My father A. R. Luria. Moscow: Gnozis. [In Russian] 
Volunteer group of the SUSU "Flame" (2015). Going to visit Luria: A small trip of a volunteer group. Retrieved from https://psyrazv.susu.ru/372-2/ [In Russian]

Vygotsky, L.S. (1997). The collected works of L.S. Vygotsky: Vol. 3. Problems of the theory and history of psychology [R. W. Rieber \& J. Wollock, Eds.]. London, UK: Plenum Press.

Zeigarnik, B. V., \& Rubinstein, S. Ya. (1982). The contribution of Luria to abnormal psychology during the Great Patriotic War (the Second World War). In E. D. Homskaya (Ed.), A. R. Luria and contemporary psychology (pp. 68-71). Moscow: Moscow University Press. [In Russian]

\section{Appendix \\ Приложение}

Это приложение мы решили дать, поскольку текст «Дневника работы» представляет собой личные записи. В какой-то мере эти записи - вынесенная вовне внутренняя речь. Перевод такого текста на иностранный язык не исключает возможность субъективной интерпретации написанного. Чтобы избежать этого риска и позволить читателям самим ознакомиться с первоисточником, в приложении мы публикуем записи на языке оригинала. В тексте «Дневника» содержатся сокращения. Их объяснение дано в квадратных скобках. Неразборчивые слова заключены в угловые скобки, а вставленные слова - в фигурные скобки.

\section{Дневник работы ${ }^{1}$}

\section{I.42}

Обсуждение опытов с коммоционным² больным (Дехтерев).

а) Тайна замедленности; расшифровка замедленности как результата системного распада, и отсюда $\rightarrow$ опроизвольнение всех компонентов.

b) Память: уплывание следов! вплетение любых компонентов мнестического плана (опыт с воспроизведением рассказа, [прослоенного] другими ff \{функциями\}).

c) Сохранность логических компонентов.

\section{I.42}

Височная афазия: Чусовитин. Грубый височный синдром. Рождение парафазий из неудержания словесных образов (нечеткость $<$ Bereich'oв $>^{3}$ )

- опыт с повторением [двойных] слов

(планирование темы Бейн ${ }^{4}$ ).

${ }^{1}$ Обложка и страница из «Дневника» представлены на рис. 8 и 9 (с. 180-181).

${ }^{2}$ Коммоционный синдром - совокупность общемозговых симптомов, вызванных механической травмой головного мозга.

${ }^{3}$ Bereich (нем.) - зона, область. См. запись от 9.ІІ.42 и сноску 9.

${ }^{4}$ Э.С. Бейн - известный психолог-афазиолог, сотрудник госпиталя, защитила диссертацию о сенсорной афазии. В «Травматической афазии» Лурия ссылается на ее исследования 11 раз. 


\section{I.42}

Опыт с Сосковым: (1) Псевдо-семантические расстройства (материалы к отграничению височно-афазических от семантических нарушений (семантические расстройства при неудержании словесных образов - [ср.] первичная сохранность смысловых отношений, состояния интеллекта).

(2) Сохранность повествовательной речи.

На правой стороне: Опыт на повествовательную речь:

нарушена при лобных афазиях (ср. резкую диссоциацию реактивной и повествовательной речи у Светлова и др.);

сохранна - при височных и теменных расстройствах (этой диссоциации нет: ср. [Гтевич], Сосков и др.)

\section{I.42}

Опыт с Усатовым: Моторика: Типичный пример подкорковых нарушений моторики: нарушение двигательных поз + дизметрия + позиционная апраксия - при сохранности всех видов произвольно-организованных движений.

NB: Ранение висок-подкорка $\rightarrow$ движения премоторного типа идут хорошо!!

На правой стороне: NB: Моторика:

1. Премоторное нарушение (чистое) - нет кинетических мелодий, схем...

2. Премоторно-подкорковое нарушение - нет кинетических схем + лишние движения (ср. Нурмуханов, ср. Алипов!).

\section{3. Чистое подкорковое}

(височное подкорковое [нарушение] $\rightarrow$ позиционные нарушения, лишних движений нет) (ср. височные подходы группа!: Федоров, Усатов!)

\section{I.42}

Опыт с Федоровым (чистый височно-подкорковый синдром)

(1) Отсутствие афазии при <поражении> левой передне-подкорковой области

(2) Полная сохранность структуры интеллектуальных операций при нарушении ее динамики (Sperrung 5 <3 буквы нрзб>)

(3) Мнестический распад - знаний (остатки коммоционного синдрома!)

(4) Разработка количественных проб на истощаемость.

На правой стороне: Сравни отрицательные случаи височных поражений

Федоров: передне-височный синдром: только амнестические компоненты в произвольной речи при отсутствии амнезии в назывании = деактивация речи: нарушение единства мышления/ речь (динамика).

\footnotetext{
${ }^{5}$ Sperrung (нем.) - блокирование.
} 


\section{I.42}

(1) Опыт с Блинниковым: Пример функционально-протрагированного ${ }^{6}$ афазического синдрома!! $\underline{\mathbf{N B}}$ !

На правой стороне: функционально-протрагированная афазия!

(2) Разработка краткой схемы исследования коммоционных больных (с Зейгарник)

\section{II.42}

Разбор Башинского. 1) Лобный синдром нарушения мышления: нарушение деятельности мышления: замысел, создание мысленного Bereich'a ${ }^{8}$, «закидывание удочки в будущее».

У лобного больного невозможно создание Проблемы (т. е. пустого Bereich'а, который координирует соответствующие рассуждения, к которому подравнивается течение рассуждения); у него невозможно и переживание ошибки, подлинный акт проверки и т.д. Все заменяется Kurzschluss'ами и течением мысли по типу "Ergänzung"10 до целого;

У него невозможна и тема, и диалог.

На правой стороне: $\underline{\mathrm{NB}}$ : Диалог как метод вынесения наружу внутренней диалектики больного!

\section{II.}

Опыт с Дурягиным: Подкорковое страдание мышления: оно построено по типу дезавтоматизации, «мышление не сразу», но при полной сохранности всех сложных форм интеллектуальных процессов, при сохранности первичной памяти и первичной волевой установки.

\section{II.}

1) Опыт с Усайковым. Особенности в мышлении при подкорковых поражениях: нарушения в первом звене - схватывании: [здесь] четкость структуры заменяется контаминацией и поэтому строится по сновидным механизмам; дальнейшее течение мышления вполне возможно

2) Опыт с Меньшиком: ясный лобный синдром штампов

NB: $100-2: 89-83,79-73,69-63$

На правой стороне: $\underline{\mathrm{NB}}$

\section{II.}

1) Разбор Кадашева. Ясный синдром базальной лобной доли: полное выпадение аффективного обобщения!

На правой стороне: распад аффективного обобщения!

${ }^{6}$ Протрагированный - затяжной.

7 Б. В. Зейгарник (1900-1988) - всемирно известный патопсихолог, ученица К. Левина и Л. С. Выготского, сотрудник госпиталя.

${ }^{8}$ Bereich (нем.) - зона, область, т. е. Лурия имеет в виду выделение смысловой зоны, фиксирующей содержание будущего высказывания /плана деятельности.

9 Kurzschluss (нем.) - короткое замыкание, переносное значение - импульсивная догадка.

${ }^{10}$ Ergänzung (нем.) - дополнение. 
2) Опыт с Беловым: еще подкорковый лобный синдром (замедленность, [отсутствие отношения]).

На правой стороне: Федоров и др.

\section{II.}

1) Опыт с Кондратьевым и Шевченко: Правая лобная доля [дает] неизменно нарушение оценки ритмов при возможности их выполнения.

На правой стороне: NB. Правая лобная доля = организация времени.

2) Опыт с Шевченко: Больной, раз выработавши штамп при чтении отрывка («У одного хозяина была курица, которая несла по трое яиц» $\left.{ }^{11}\right)$, не только сохранил этот штамп в течение 3-х недель и после однократного чтения дал его через 3 недели, - но оказался не в состоянии поддаться переобучению, и - даже после повторного чтения с разъяснением ошибки - все же продолжал давать еe!!

3) Опыт с Сычевым (левая лобная доля). Четкая формулировка лобного дефекта интеллекта:

а) Нарушение нормальных соотношений мысли и речи: «язык идет впереди мысли», а его оговорки вплетения - «оговорки невнимания».

На правой стороне: NB: К единства мысли и речи).

b) Нарушение мышления не в самой мыслительной операции (например, счета), а в невозможности удержать условия в памяти.

Здесь - снова своеобразный дефект памяти на мысли - при полной сохранности и самой памяти и самого интеллекта (сравни: полная сохранность опытов на запоминание слов).

\section{II}

1) Опыт с Усатовым. Нарушение мышления - в нарушении направленности

2) Опыт с майором Новицким: При относительной сохранности - нарушение в исполнении ритмов.

На правой стороне: Сравни: правая лобная доля!!

\section{II.}

Опыт с Сизиковым. Коммоционный больной может и не давать нарушений премоторного типа!

\section{4-25.II.}

Опыт с Горюновым. Чистая семантическая афазия (=невозможность Zusammensehen ${ }^{12}$ семантических структур!).

11 А.Р. Лурия обычно рассказывал больным историю: «У одного хозяина курица несла золотые яйца. Он захотел побольше золота и зарезал курицу. А внутри золота не было». Больной заменяет слова «золотые яйца» на «трое яиц». Далее он эти слова стереотипно повторяет.

${ }_{12}$ Zusammensehen (нем.) - здесь и далее симультанное видение. 
26.II.

1) Опыт с Горюновым. Типичные конфликты, колебания семантического афазика («более светлый = менее светлый» и т.д.)

2) Опыт с Сычевым - Невозможность перейти от плана к связному изложению, повествованию.

На правой стороне: План добной афазии.

3) Опыт с Усатовым. Первичная амнезия при подкорковом страдании.

27.II.

Опыт с Горюновым. Анализ строения фразы (страдательный залог) «Солнце освещается землей». Механизм оценки фразы есть механизм практического размещения слов и узнавание правильного смысла. Анализ, осознание смысла невозможен.

28.II.

1) Опыт с Сычевым: Изложение отрывка. Основные положения о лобной афазии.

Лобная афазия = страдание динамической стороны внутреннего слова $=$ прерывание, утекание слова $\rightarrow$ невозможность охватить единство фразы = ускользание конца фразы

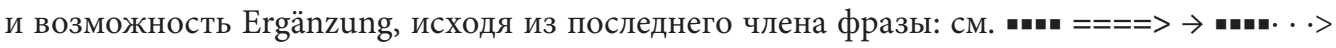

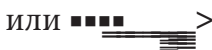

и невозможность сохранить единство мысли (см. схему Лурия на рис. 9, с. 181).

На правой стороне: $\underline{\mathrm{NB}}$

2) Опыт с Горюновым: Анализ понимания метафор, пословиц и 4-й лишний. Проблема отношения семантической афазии к деменции. Можно ли предполагать сохранное категориальное мышление при нарушении Zusammensehen??

3) Опыт с Горюновым: тест, вскрывающий особенность реакций больных на длительную работу.

\section{III.1942}

Опыт с Горюновым: 1) Возможность схватывать отношения общности!! 2) Сохранность общих понятий - при амнезии на них - и при соскальзывании в конкретный план!

На правой стороне: фигурная скобка к 1) и 2) NB!

\section{III.42}

1) Опыт с Карабановым (премоторная афазия) 1) чистая форма дезавтоматизации; 2) нарушение схватывания «не сразу».

На правой стороне: NB: Один из основных феноменов: дезавтоматизация схватывания! (динамическое нарушение интеллектуальных [процессов])!!

2) Опыт с Горюновым: динамика понятий: возможность сравнения, обобщения но тенденция к соскальзыванию в план комплексного мышления. 


\section{III.42}

1) Опыт с Горюновым. Аналогии. Возможность овладения аналогией и переносом! Вторичные трудности в этом.

2) Усатов. Трудности заучивания (первичное нарушение памяти - заучивание осмысленного текста легче, чем заучивание стихотворения).

\section{III.42}

Опыт с Горюновым. Счет. Невозможность сразу же оценить многозначное число. Схватывание многозначного числа (a) по наглядной аналогии или (b) путем наложения внешней сетки.

\section{III.}

Схема лобных афазий ${ }^{13}$

\section{Афазия Брока}

(ее тесная обратная связь с зоной Вернике.

Щербаков!

Звуковая аграфия при <исследовании>

ее тесная обратная связь с теменной зоной:

семантические расстройства при <исследовании>)

\section{Премоторная афазия}

Дезавтоматизация речи, [мотор.], [схватыв.]

Мерскалов, денервационное нарушение письма, Карабанов

относительная сохранность мысли

Лобная афазия (или пара-афазическое состояние)

(нарушение связи мысли с речью - внутренней речи.

Рвущаяся нить мысли.

Нарушение повествования, изложения, динамики Aussage ${ }^{14}$ и Propositional speech ${ }^{15}$ )

\section{III.42}

1) Опыт с Горюновым. Счет: Трудности не в понятии числа, разряда, знака, - а в схватывании числа, совмещении его компонентов при операциях (особенно в уме).

13 Данная классификация лобных афазий отличается от предыдущих и последующих. Здесь под «лобной афазией» понимается динамическая афазия. «Премоторная» афазия описывается в «Травматической афазии» как «нарушения речи при поражении “пограничных” разделов премоторной зоны» (Luria A. R., 1970, pp. 176-185; см. также: Akhutina, 2016).

${ }^{14}$ Aussage (нем.) - высказывание.

${ }_{15}$ Propositional speech (англ.), от proposition - предложение, утверждение, т.е. предикативная повествовательная речь. Лурия цитирует положение Джексона (Jackson, 1868, 1869/1932) “Тo speak is to propositionize" (Luria A. R., 1976, p. 37). 
2) Опыт с Карабановым: а) Резчайшая аспонтанность речи - невозможность исходить из внутреннего плана, невозможность повествовательной речи

b) Доступность «Ergänzungsfragen ${ }^{16}$ (прямых вопросов) и недоступность косвенных вопросов (требующих прослойки мысли)

На правой стороне:

NB: прямые вопросы (Ergänzungsfragen) + ср. детский

косвенные вопросы (требующие - возраст 2-2,5 года

прослойки мысли!)

\section{2.-13.III.42}

1) Опыт с Моисеевым: Грубая теменная и височная афазия

2) Гдевич (Кауфман \{О. П. Кауфман\}) - полная сохранность ритмов.

На правой стороне: NB!!!

3) Опыт с Карабановым: Грубое нарушение излагающей (повествовательной) речи; нарушение активных форм; нарушение схватывания.

\section{Продолжение следует}

Original manuscript received January 19, 2020

Revised manuscript accepted February 20, 2020

To cite this article: Akhutina, T. V., \& Pylaeva, N. M. (2020). Luria in Kisegach. Part 1. Lurian Journal, 1 (1), 171-194. DOI: 10.15826/Lurian.2020.1.1.12

${ }^{16}$ Ergänzungsfragen (нем.) - вопросы, требующие дополнения. В «Травматической афазии» Лурия различает два типа вопросов в диалоге, одни не требуют поиска новых формулировок («Ты сегодня обедал?», «Ты умеешь читать?»), другие, например, «Как ты был ранен?», требуют от больного «проявить специальную активность в нахождении новых формулировок» (Luria A. R., 1970, pp. 299-300). 